\title{
Citrus limon (L.) Burm f. Essential Oil Has Anxiolytic and Sedative Properties by Modulating GABAA- Receptors
}

Max Denisson Mauricio Viana ${ }^{1^{\star}}$

https://orcid.org/0000-0002-1650-4460

Geraldo Jose da Silva Neto ${ }^{2}$

https://orcid.org/0000-0002-4872-9269

Alyne Almeida de Lima $^{3}$

https://orcid.org/0000-0002-6174-7402

Anderson Brandão Leite ${ }^{3}$

https://orcid.org/0000-0003-2071-2016
Isis Torres Souza ${ }^{2}$

https://orcid.org/0000-0002-5679-0035

\author{
Antônio Euzébio Goulart Santana ${ }^{2}$ \\ https://orcid.org/0000-0001-5025-9107 \\ Eliane Aparecida Campesatto ${ }^{3}$ \\ https://orcid.org/0000-0003-3689-888X
}

\section{Magna Suzana Alexandre Moreira ${ }^{3}$ https://orcid.org/0000-0002-9979-1994}

${ }^{1}$ Federal University of Bahia, College of Pharmacy, Salvador, Bahia, Brazil; 2Federal University of Alagoas, Institute of Chemistry and Biotechnology, Maceió, Alagoas, Brazil; ${ }^{3}$ Federal University of Alagoas, Institute of Biological and Health Sciences, Maceió, Alagoas, Brazil.

Received: 2020.04.07; Accepted: 2020.04.17.

*Correspondence: max.viana@ufba.br; Tel.: +55-71-32836948.

\section{HIGHLIGHTS}

- Essential oils from Citrus genus induce anxiolytic-like effects;

- Citrus limon essential oil acts as hypnotic-sedative and anxiolytic drug;

- GABAergic pathway is suggestively related to Citrus limon essential oil action;

- No motor impairment was observed with Citrus limon essential oil.

Abstract: The high prevalence of anxiety disorders associated with pharmacotherapy side effects have motivated the search for new pharmacological agents. Species from Citrus genus, such as Citrus limon (sicilian lemon), have been used in folk medicine as a potential therapy to minimize emotional disorders. In order to searching for new effective treatments with fewer side effects, the present study evaluated the anxiolytic mechanism of action and the hypnotic-sedative activity from the Citrus limon fruit's peels essential oil (CLEO). Adults male Swiss mice were submitted to barbiturate-induced sleep test; elevated plus-maze (EPM) and light-dark box (LDB) (evaluation of the mechanism of action); rotarod; and catalepsy tests. CLEO oral treatment decreased latency and increased the sleep total time; moreover it induced in animals an increased the number of entries and percentage of time spent into open arms of the EPM; an increased the number of transitions and the percentage of time into light compartment in the LDB; which were only antagonized by flumazenil pretreatment, with no injury at motor function. Thus, results suggest that CLEO treatment induced an anxiolytic behavior suggestively modulated by the benzodiazepine binding site of the $\mathrm{GABA}_{\mathrm{A}}$ receptor or by an increase of GABAergic neurotransmission, without cause impairment in the motor coordination. 
Keywords: Citrus limon; essential oil; sedative; anxiolytic; GABAergic.

\section{INTRODUCTION}

World Health Organization points anxiety as the most common psychiatric illness in the world's population and it highlights that Brazil leads the prevalence of this disorder, which encourages researches in this area, including the search for new drugs [1].

$\mathrm{GABA}_{\mathrm{A}}$ receptors are targets of several pharmacologically relevant drugs; in particular, benzodiazepines (BZD). These drugs are used for the treatment of insomnia, anxiety, epilepsy, and to facilitate muscle relaxation and anesthesia. Unfortunately, the use of benzodiazepines is limited by the development of tolerance and dependence, which are the mainly side effects that occurs after prolonged administration [2].

As current pharmacotherapy is not effective for all patients, the search for better anxiolytic drugs with fewer side effects is needed [3]. Currently, more attention has been paid to plant-derived drugs, especially from essential oils, which demonstrate efficacy by reducing the symptoms of anxiety and, compared to traditional medicines, essential oils have fewer side effects $[4,5]$.

In the Rutaceae family, essential oils of the genus Citrus are mainly extracted from the peels of fruits since the species in this group possess odoriferous substances, which showed anxiolytic-like effect both in animal models [6-8] and clinical trials [9-11].

Studies report that monoterpenes present in these plants and their synthetic derivatives have several pharmacological properties in the central nervous system (CNS), such as anxiolytic, anticonvulsant, and neuroprotective. Some of these substances are: linalool [12,13], limonene, and $\alpha$-pinene [14,15]. This last compound, for example, displayed anxiolytic and sleep-increasing behaviors by direct binding to $\mathrm{GABA}_{\mathrm{A}^{-}}$ Benzodiazepine receptors $\left(G A B A_{A}-B Z D\right)$ and forcing as a partial modulator at BZD binding site, in a molecular docking model [16].

Within biological potentials of citrus plants context, Citrus limon (L.) Burm. f. (sicilian lemon) is worldwide known and used in folk medicine for central disorders which reinforces the need for further studies in order to confirm the ethnopharmacological use and amplify the study and importance of essential oils [17].

Considering the need for research and development of new effective therapeutic agents with hypnotic and anxiolytic properties and more tolerable, the present study aimed to evaluate the hypnotic-sedative and anxiolytic effects, along with its possible mechanism of action, and the likely motor coordination impairment in mice treated with Citrus limon fruit's peels essential oil (CLEO) per os (p.o.).

\section{MATERIAL AND METHODS}

\section{Animals}

Adults male albino Swiss mice (6-8 weeks), with an average weight of $30 \mathrm{~g}$, provided by the Central Animal House of Federal University of Alagoas, were used in pharmacological tests. The animals were kept in polypropylene boxes in a room with controlled temperature $\left(22 \pm 1^{\circ} \mathrm{C}\right)$, with a 12-hour light/dark cycle (dark phase: 19:00-7:00), for at least $72 \mathrm{~h}$ before testing for acclimatization. They were fed with water and a commercial solid diet ad libitum (Labina ${ }^{\circledR}$, Purina, Brazil). They were fasting six hours before oral treatment in order to avoid food interactions. All proceedings and experimental models were executed according to experimental protocols designed in conformation with the Ethical Principles in Animal Research as adopted by the Brazilian Society of Laboratory Animal Science. Ethics Commission on Animal Use of the Federal University of Alagoas approved the experimental models present in this study by the protocol number $\mathrm{n}^{\circ}$ $55 / 2013$.

\section{Drugs}

Haloperidol (HALO, Halo®, Cristália, Brazil) was used as a competitive antagonist of dopamine binding; sodium pentobarbital (PENTO, Abott, Brazil) was used as a sleep inducer; diazepam (DZP, Compaz®, Cristália, Brazil), standard anxiolytic drug, was used as agonists of $\mathrm{GABA}_{A}$; buspirone hydrochloride (BUSP, Pharmanostra, Brazil) and $\alpha$-methylserotonin maleate salt ( $\alpha-\mathrm{Me}-5-\mathrm{HT}$, Sigma-Aldrich, USA) were used as agonists of 5- $\mathrm{HT}_{1 \mathrm{~A}}$ and 5- $\mathrm{HT}_{2 \mathrm{~A} / \mathrm{C}}$ receptors, respectively; flumazenil (FLU, Flumazil ${ }^{\mathrm{B}}$, Cristália, Brazil), NAN190 hydrobromide (NAN-190, Sigma-Aldrich, USA) and ketanserin (+)-tartrate salt (KET, Sigma-Aldrich, USA) were utilized as antagonists of benzodiazepine binding, 5- $\mathrm{HT}_{1 \mathrm{~A}}$ and $5-\mathrm{HT}_{2 \mathrm{~A} / \mathrm{C}}$, respectively. In the intraperitoneal injections (i.p.), all agonists and antagonists were solubilized in isotonic saline solution (SAL, 
0.9\%). In oral administration (p.o.), Citrus limon essential oil (CLEO, Ferquima Ind. and Com. Ltda, Brazil) was emulsified with polyoxyethylene sorbitan monooleate (Tween $80 \AA, 0.01 \% \mathrm{v} / \mathrm{v}$ ) in SAL $0.9 \%$, which was also used to treat the negative control groups (vehicle). All of the substances were freshly prepared on the test day and were administered at $10 \mathrm{~mL} / \mathrm{kg}$ of body weight, except FLU, which was administered at $20 \mathrm{~mL} / \mathrm{kg}$ due to the concentration $(0.1 \mathrm{mg} / \mathrm{mL})$ of its commercial form.

\section{Analysis of the essential oil composition}

Sample of the CLEO was suspended in $1 \mathrm{~mL}$ of ethyl acetate (P.A., Merck, Germany) and $1 \mu \mathrm{L}$ of this suspension was analyzed by gas chromatography coupled to mass spectrometer (GC/MS, Shimadzu, model QP-5000) equipped with a fused silica capillary column JW DB-5 (30 m x $0.25 \mathrm{~mm} \times 0.25 \mu \mathrm{m})$. The electron impact technique $(70 \mathrm{eV})$ was used and injector temperature was $250 \stackrel{\circ}{ } \mathrm{C}$, as well as detector temperature was $200^{\circ} \mathrm{C}$. The carrier gas was helium at the working rate of $1.0 \mathrm{~mL} / \mathrm{min}$. The column temperature was initially $50{ }^{\circ} \mathrm{C}$ and then was gradually increased at the rate of $5^{\circ} \mathrm{C} / \mathrm{min}$ up to $180^{\circ} \mathrm{C}$ and after up to $300^{\circ} \mathrm{C}$ at the rate of $8^{\circ} \mathrm{C} / \mathrm{min}$. For detection of the oil components, a flame ionization detector was used set up at $200^{\circ} \mathrm{C}$. The identification of the components of the essential oil was effected through of comparison of substance mass spectrum with the database of the GC/MS (NIST 62.lib), literature and retention index [18].

\section{Pharmacological evaluations}

\section{Pentobarbital-induced sleep test}

Experimental procedure was performed as described by Carlini and Burgos [19]. Mice were distributed in groups of $8(n=8)$ and pre-treated (p.o.) with vehicle, CLEO and DZP. It is well established that benzodiazepines act as anxiolytics at low doses and that they induce sedation and myorelaxant effects at higher doses (20). Therefore, DZP (1.5 mg/kg, i.p.) was used as a positive control for anxiolytic-like effects, and DZP (2.5 and $5.0 \mathrm{mg} / \mathrm{kg}$, i.p.) as a positive control for sedative and myorelaxant effects, and CLEO at the doses 30,100 , and $300 \mathrm{mg} / \mathrm{kg}$, p.o. for this test. The test started sixty minutes after the treatment with DZP or thirty minutes after CLEO and vehicle treatments.

\section{Elevated plus-maze test (EPM)}

The test followed procedure described by Lister [21] and Pellow and File [22]. Experimental groups $(n=$ 8 , per group) were pre-treated with vehicle $(10 \mathrm{~mL} / \mathrm{kg}$, p.o.), CLEO $(30,100$, and $300 \mathrm{mg} / \mathrm{kg}$, p.o.) or DZP $(1.5 \mathrm{mg} / \mathrm{kg}$, i.p). The test started sixty and thirty minutes after i.p. and oral treatments.

\section{Light-dark box test (LDB)}

After treatment (vehicle $10 \mathrm{~mL} / \mathrm{kg}$, p.o; DZP $1.5 \mathrm{mg} / \mathrm{kg}$ i.p.; and CLEO 30, 100, and $300 \mathrm{mg} / \mathrm{kg}$, p.o.), each animal was individually placed in the center of the light compartment facing the dark compartment, in which the test was performed as described by Crawley and Goodwin [23].

\section{Mechanisms involved in the anxiolytic-like activity of CLEO}

The animals were pre-treated with flumazenil (2 mg/kg; 15 min pre-treatment) [24]; NAN-190 (0.5 mg/kg; $20 \mathrm{~min}$ pre-treatment) [25]; or Ketanserin ( $0.5 \mathrm{mg} / \mathrm{kg}$; $20 \mathrm{~min}$ pre-treatment). After antagonists' administration, vehicle (10 mL/kg, p.o.); DZP (1.5 mg/kg, i.p); buspirone (10 mg/kg, i.p.); $\alpha$-methylserotonin (1 mg/kg; i.p.); or CLEO (300 mg/kg, i.p.) were administrated, and anxiolytic behaviors were analysed in the EPM and LDB tests, after 60 minutes of the treatment with DZP and 30 minutes for others.

\section{Assessment of central side effects on motor performance}

\section{Rota-rod test (RRT)}

In this test, groups of pre-selected animals $(n=8)$ were treated with vehicle $(10 \mathrm{~mL} / \mathrm{kg}$, p.o.), DZP $(1.5$ $\mathrm{mg} / \mathrm{kg}$, i.p.) or CLEO (30,100, and $300 \mathrm{mg} / \mathrm{kg}$, p.o.). Sixty and thirty minutes after the i.p. and oral treatments, the animals were placed in the equipment and the test was performed as described by Dunham and Miya [26]. 
Catalepsy test (CT)

Catalepsy, defined as the acceptance and retention of abnormal posture, was measured by means of the bar test, which is described by Sanberg and coauthors [27]. Mice were distributed in groups of $8(n=8)$ and were treated with vehicle $\left(10 \mathrm{~mL} / \mathrm{kg}\right.$, p.o.), haloperidol (1 mg/kg i.p.) - a competitive antagonist of $D_{2}$ receptors - or CLEO (30, 100, and $300 \mathrm{mg} / \mathrm{kg})$.

\section{Statistical analysis}

All of the statistical analyses were made using GraphPad Prism® 5.01 Software (Demo). The results were expressed as the means \pm SEM. Significant differences between experimental groups $(n=8)$ were detected by one-way ANOVA (analysis of variance) followed by Dunnett's test. Effects were considered significant at $p<0.05$.

\section{RESULTS}

\section{Essential oil composition}

The analysis by GC-MS of CLEO permitted identification of eight constituents, exclusively monoterpenes: $\alpha$-thujene (1), $\alpha$-pinene (2), Sabinene (3), $\beta$-pinene (4), myrcene (5), p-cymene (6), (R)-limonene (7) and $\gamma^{-}$ terpinene (8) - Figure 1, and Table 1.

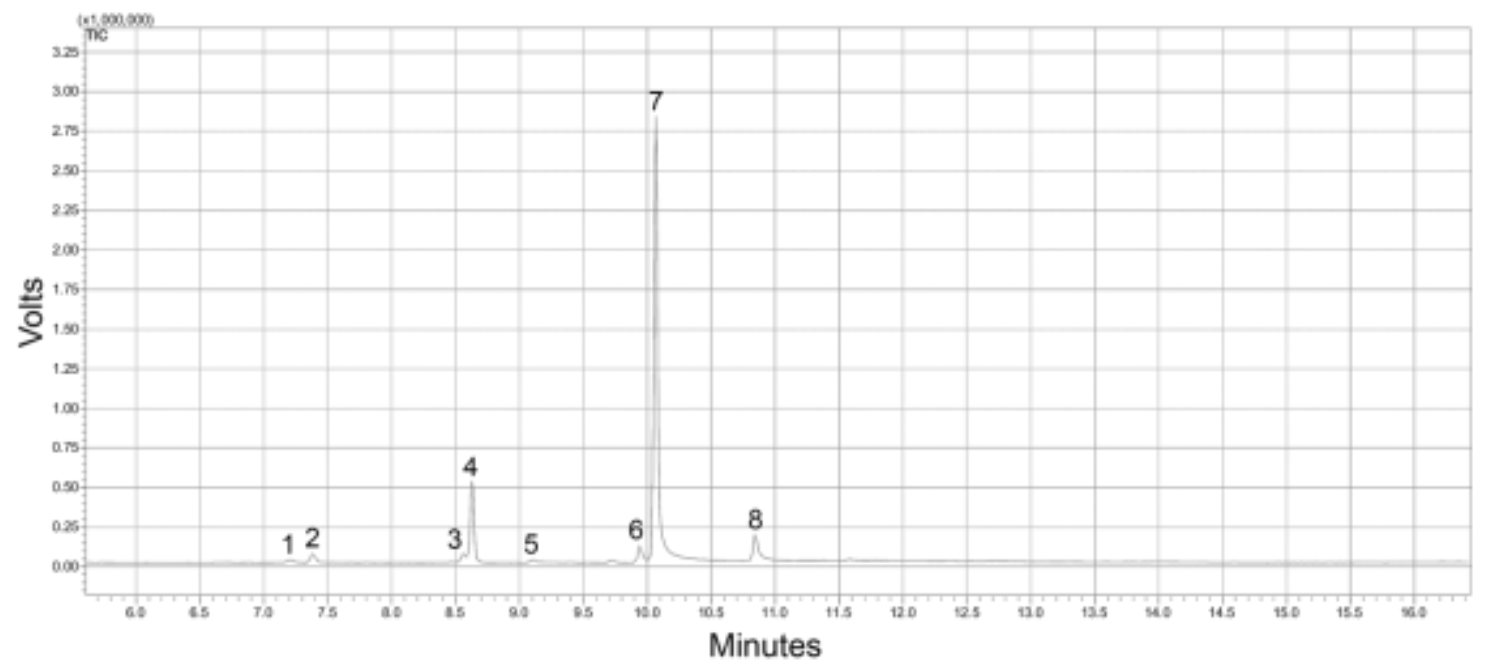

Figure 1. Representative gas chromatogram of essential oil extracted from Citrus limon (instrumental conditions are described in Material and Methods).

Table 1. Volatile composition of Citrus limon essential oil.

\begin{tabular}{crrlr}
\hline Peak & RT $^{1}$ & $\mathbf{R I}^{2}$ (DB-5) & Compounds & \multicolumn{1}{c}{$\%$} \\
\hline 1 & 7.212 & 927 & $\alpha$-thujene & $1.5 \%$ \\
2 & 7.387 & 939 & a-pinene & $4.0 \%$ \\
3 & 8.593 & 974 & Sabinene & $2.0 \%$ \\
4 & 8.629 & 981 & $\beta$-pinene & $15.0 \%$ \\
5 & 9.101 & 992 & Myrcene & $1.5 \%$ \\
6 & 9.561 & 1026 & p-Cymene & $5.0 \%$ \\
7 & 10.065 & 1033 & (R)-limonene & $65.0 \%$ \\
8 & 10.843 & 1074 & Y-terpinene & $5.0 \%$ \\
- & - & & - Total identified & $\mathbf{9 9 . 0 \%}$ \\
\hline
\end{tabular}

${ }^{1} \mathrm{RT}$ : retention time; ${ }^{2} \mathrm{RI}$ : retention index by Adams [18].

From these data, it is possible to affirm that the highest peak (retention time $10.065 \mathrm{~min}$ ) in the GC analysis of essential oil belongs to (R)-limonene, which also shows the higher content $(65.0 \%)$, characterizing it as major compound in the CLEO, followed by the second peak, $\beta$-pinene (retention time: $8.629 \mathrm{~min}$; area: $15.0 \%$ ) - Table 1. 


\section{Sedative and anxiolytic-like responses from CLEO in mice}

In the pentobarbital-induced sleep test, the oral administration of CLEO at the maximum dose (300 $\mathrm{mg} / \mathrm{kg})$ decreased the sleep latency time $(\mathrm{p}<0.001)$, as well the two doses of DZP $(2.5$ and $5 \mathrm{mg} / \mathrm{kg}$, i.p.) $(p<0.001)$, all compared to vehicle group (Figure $2 A)$. In addition, these treatments also increased significantly $(p<0.001)$ lengthened the duration of the sodium pentobarbital-induced hypnosis in mice in suggesting an enhanced pentobarbital effect (Figure 2B). There were no statistically significant differences among the dose of $300 \mathrm{mg} / \mathrm{kg}$ CLEO and the two doses of DZP on both parameters evaluated.

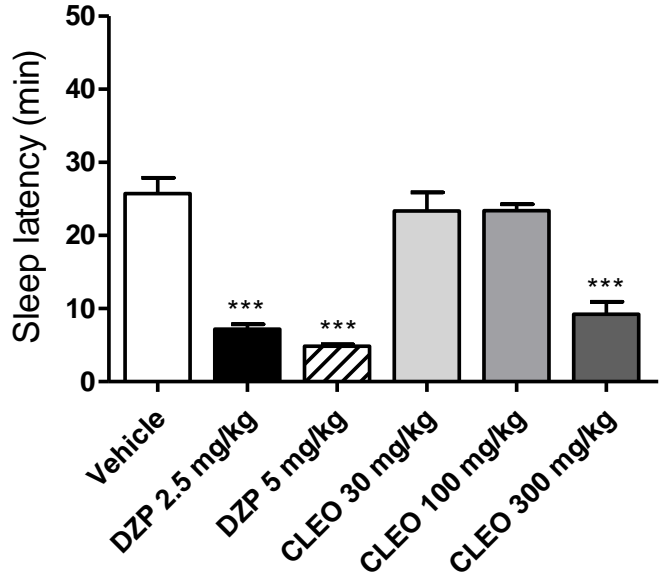

(a)

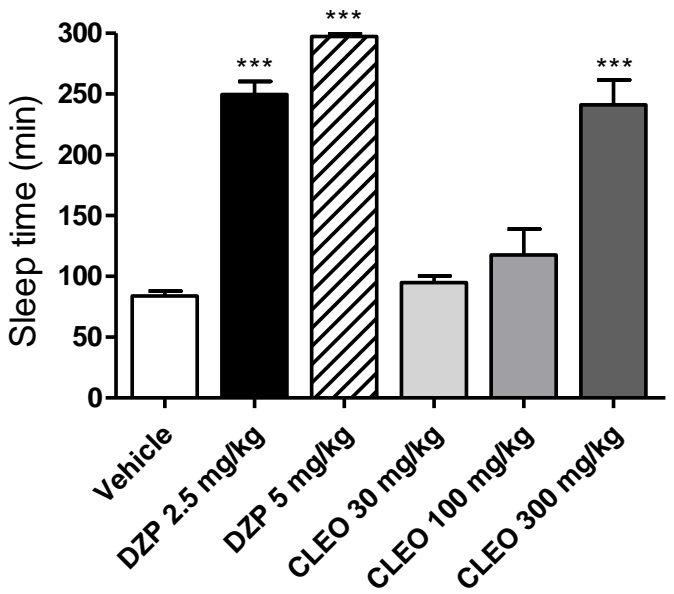

(b)

Figure 2. Effects of Citrus limon essential oil (CLEO) on the sleep latency, in minutes (a), and sleeping time, in minutes (b), on the pentobarbital-induced sleep test in mice. Vehicle (10 mL/kg, p.o.), Citrus limon essential oil (CLEO, 30, 100, and $300 \mathrm{mg} / \mathrm{kg}$, p.o.) and diazepam (DZP, 2.5 and $5 \mathrm{mg} / \mathrm{kg}$, i.p.). The columns and vertical bars represent the means \pm SEM of eight mice. ${ }^{* * *} p<0.001$ compared with vehicle group using ANOVA and Dunnett's test as the post hoc test.

\section{CLEO anxiolytic effect in mice}

CLEO treatment at 100 and $300 \mathrm{mg} / \mathrm{kg}$ doses induced a statistically significant increase in the number of entries into open arms $(p<0.001)$ and, consequently, the percentage of time into open arms $(p<0.001)$ compared to the vehicle group. The result was similar to the observed with the standard drug DZP treatment $(p<0.001)$ when compared to the same vehicle group - Figure 3A and 3B.

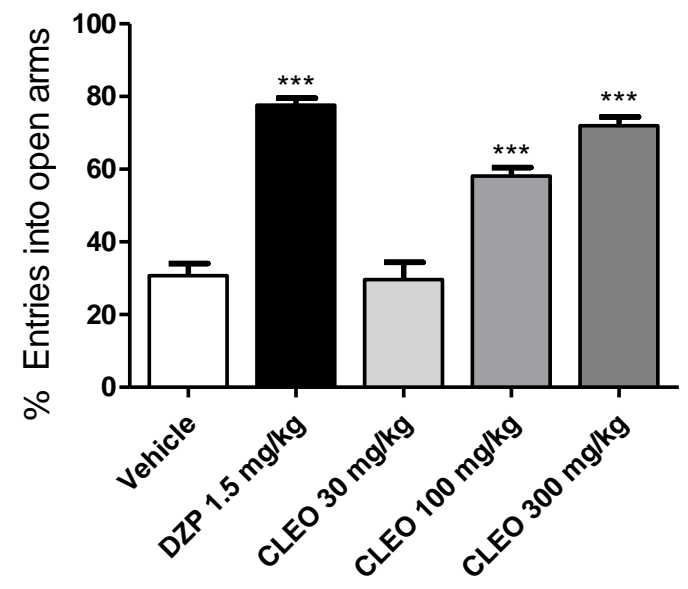

(a)

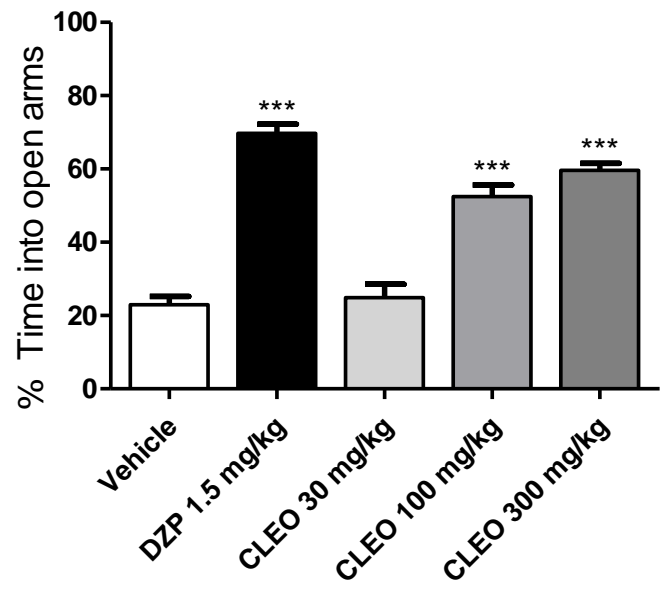

(b)

Figure 3. Effects of Citrus limon essential oil (CLEO) on the number of entries (a) and percentage of time into open arms (b), on the elevated plus-maze test in mice. Vehicle (10 mL/kg, p.o.), Citrus limon essential oil (CLEO $300 \mathrm{mg} / \mathrm{kg}$, p.o.), diazepam (DZP, $1.5 \mathrm{mg} / \mathrm{kg}$, i.p.). The columns and vertical bars represent the means \pm SEM of eight mice. ${ }^{* *} p<0.001$, compared with vehicle group using ANOVA and Dunnett's test as the post hoc test. 
The results of the CLEO treatment in the light-dark box test can be seen in Figure 4. In this test, the number of transitions between light and dark compartments was statistically increased by CLEO treatment at 100 and $300 \mathrm{mg} / \mathrm{kg}$ doses and by DZP treatment $(p<0.001)$ when compared to the vehicle group - Figure 4A. In Figure 4B it is observed that the same treatments mentioned above induced an increase in the exploratory activity of the animals by statistically increasing the percentage of time into light compartment $(p<0.001)$ as compared to the negative control group. Thus, this behavior suggests an anxiolytic effect in animals treated with CLEO.

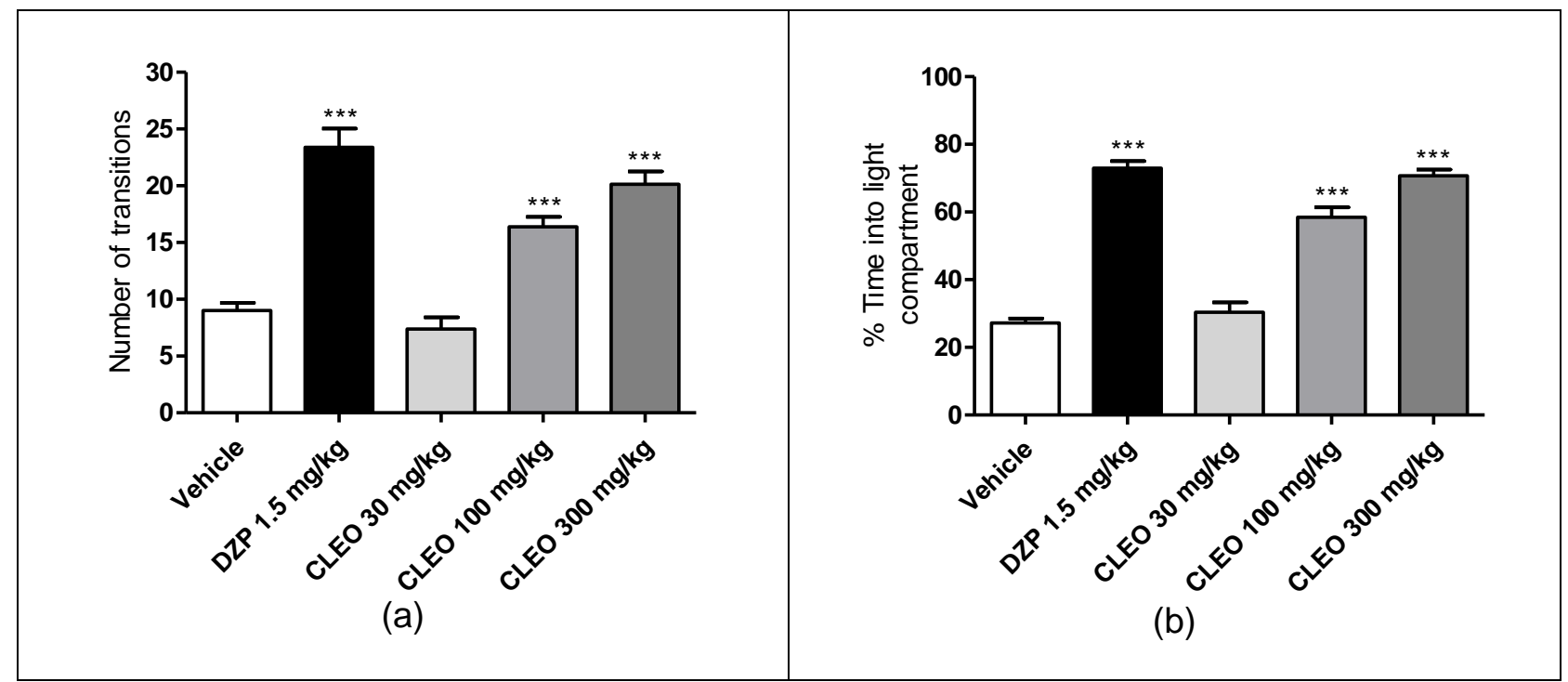

Figure 4. Effects of Citrus limon essential oil (CLEO) on the number of transitions (a) and percentage of time into light compartment (b) on the light-dark box test in mice. Vehicle (10 mL/kg, p.o.), Citrus limon essential oil (CLEO $300 \mathrm{mg} / \mathrm{kg}$, p.o.), diazepam (DZP, $1.5 \mathrm{mg} / \mathrm{kg}$, i.p.). The columns and vertical bars represent the means \pm SEM of eight mice. The columns and vertical bars represent the means \pm SEM of eight mice. ${ }^{* * *} p<0.001$, compared with vehicle group using ANOVA and Dunnett's test as the post hoc test.

\section{GABAergic neuromodulation on CLEO anxiolytic effect}

When FLU + DZP, NAN-190 + BUSP, and KET + $\alpha-M e-5-H T$ were associated, a statistically significant reversal of the behavior in the EPM parameters, such as the percentage of entries and time into open arms when compared to anxiolytics isolated use (Figure 5A and 5B). However, when the same antagonists were pre-administered and then the administration of CLEO (300 mg/kg) occurred, only FLU was able to reverse the behavioral effects evaluated, unlike the serotonergic pathways where there were no significant differences in the parameters assessed.

In the light-dark box test, both parameters analyzed, which were the number of transitions between compartments and percentage time into light compartment, for each agonists of the pathways studied were reversed from the pre-treatments with their respective antagonists. However, only FLU antagonist pretreatment significantly reversed the increase in the parameters induced by CLEO - Figure 6A and 6B suggesting that its action can be modulated via GABAergic receptors. 


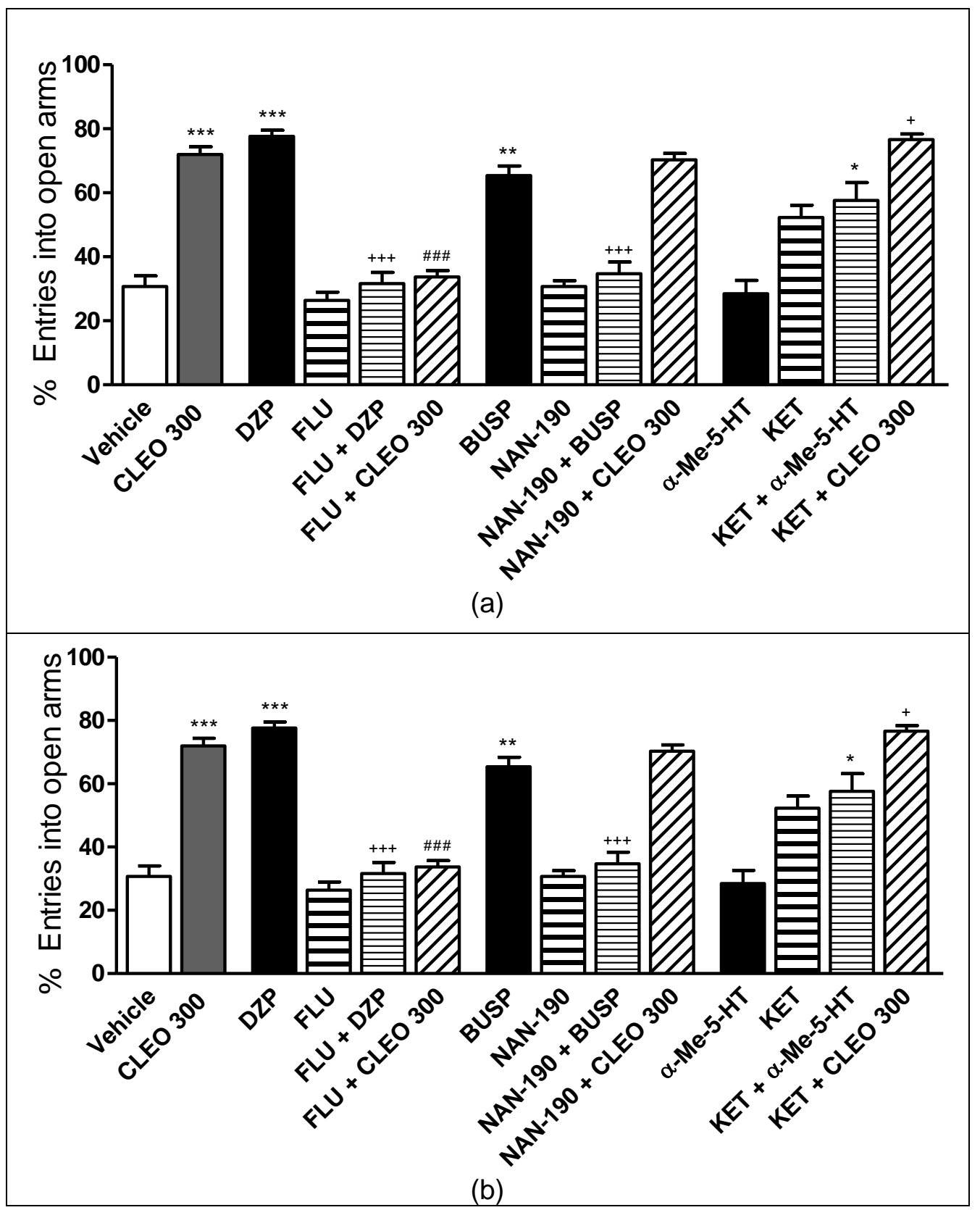

Figure 5. Effects of Citrus limon essential oil (CLEO) on the number of entries (a) and percentage of time into open arms (b), on the elevated plus-maze test in mice. Vehicle (10 mL/kg, p.o.), Citrus limon essential oil (CLEO $300 \mathrm{mg} / \mathrm{kg}$, p.o.), diazepam (DZP, $1.5 \mathrm{mg} / \mathrm{kg}$, i.p.), Flumazenil (FLU, $2 \mathrm{mg} / \mathrm{kg}$, i.p.), Buspirone (BUSP, $10 \mathrm{mg} / \mathrm{kg}$, i.p.), NAN-190 (0.5 $\mathrm{mg} / \mathrm{kg}$, i.p.), $\alpha-M e t h y l s e r o t o n i n ~(\alpha-M e-5-H T, 1 \mathrm{mg} / \mathrm{kg}$, i.p.) and Ketanserin (KET, $0.5 \mathrm{mg} / \mathrm{kg}$, i.p.). The columns and vertical bars represent the means \pm SEM of eight mice. ${ }^{*} p<0.05$, ${ }^{* *} p<0.01$, and ${ }^{* * *} p<0.001$, compared with vehicle group; $+p<0.05$ and $+++p<0.001$, compared with agonist; \#\#\# <0.001, compared with CLEO 300 group; using ANOVA and Dunnett's test as the post hoc test. 

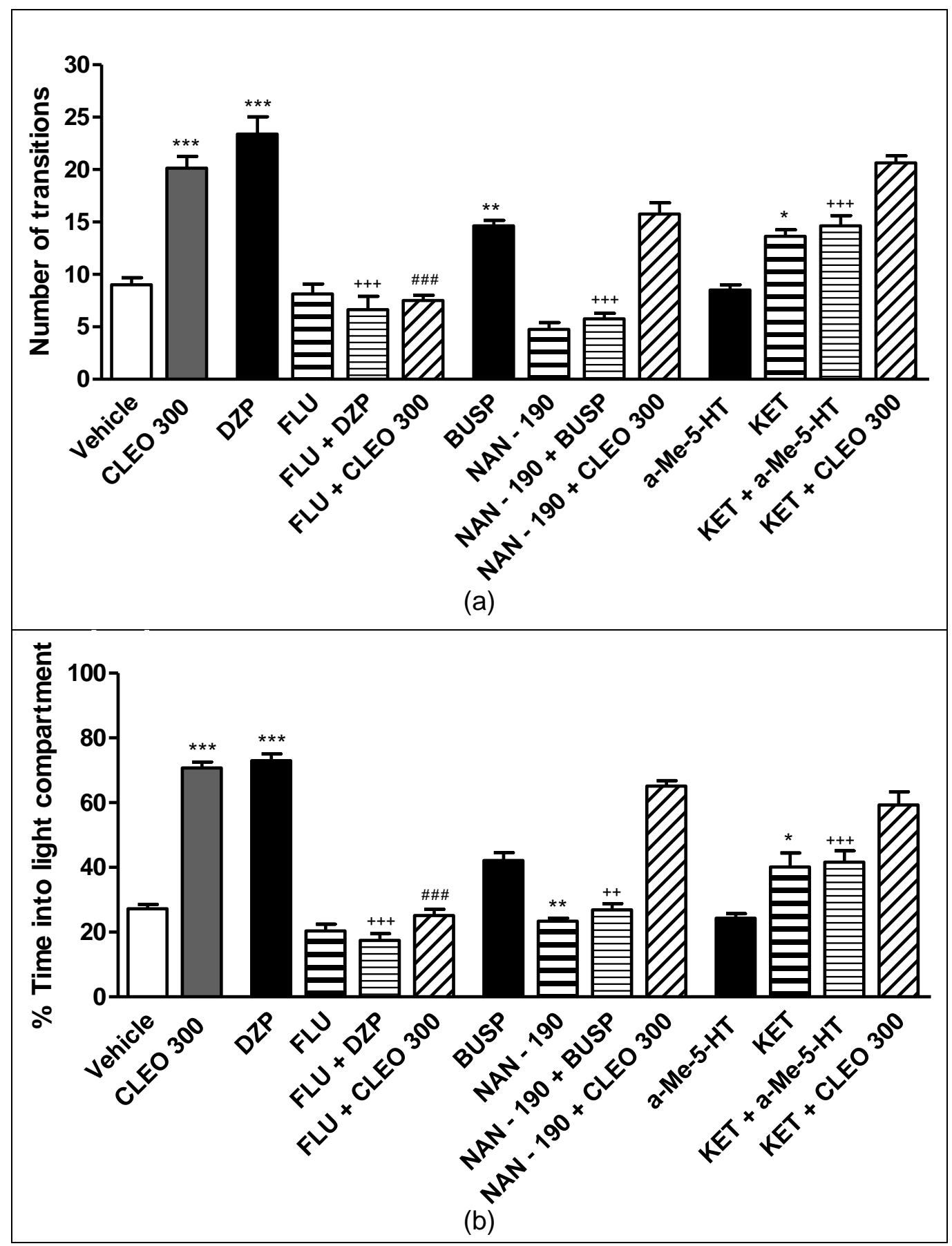

Figure 6. Effects of Citrus limon essential oil (CLEO) on the number of transitions (a) and percentage of time into light compartment (b), on the light-dark box test in mice. Vehicle (10 mL/kg, p.o.), Citrus limon essential oil (CLEO $300 \mathrm{mg} / \mathrm{kg}$, p.o.), diazepam (DZP, $1.5 \mathrm{mg} / \mathrm{kg}$, i.p.), Flumazenil (FLU, $2 \mathrm{mg} / \mathrm{kg}$, i.p.), Buspirone (BUSP, $10 \mathrm{mg} / \mathrm{kg}$, i.p.), NAN-190 (0.5 $\mathrm{mg} / \mathrm{kg}$, i.p.), $\alpha-$ Methylserotonin ( $\alpha-M e-5-H T, 1 \mathrm{mg} / \mathrm{kg}$, i.p.) and Ketanserin (KET, $0.5 \mathrm{mg} / \mathrm{kg}$, i.p.). The columns and vertical bars represent the means \pm SEM of eight mice. The columns and vertical bars represent the means \pm SEM of eight mice. ${ }^{*} p<0.05$, ${ }^{* *} p<0.01$, and ${ }^{* * *} p<0.001$, compared with vehicle group; $++p<0.01$ and $+++p<0.001$, compared with agonist; \#\#\#p<0.001, compared with CLEO 300 group; using ANOVA and Dunnett's test as the post hoc test.

\section{CLEO does not change the motor performance of mice}

The RRT was carried out to measure motor coordination impairment in mice treated with DZP or CLEO. The results, presented in Table 2, show that CLEO (at any dose) did not altered the number of falls of the rotating bar, whereas DZP $(1.5 \mathrm{mg} / \mathrm{kg}$, i.p.) significantly increased the number of falls $(p<0.001$ vs. vehicle group). Furthermore, treatment with DZP significantly reduced latency for the fall ( $p<0.001 \mathrm{vs}$. vehicle group), unlike that seen with oral treatment with the CLEO. 
Table 2. Effects of Citrus limon essential oil (CLEO) on Rota-rod test.

\begin{tabular}{lll}
\hline \multicolumn{1}{c}{ Treatments } & Number of falls & \multicolumn{1}{c}{ Latency for the fall } \\
\hline Vehicle & $0.0 \pm 0.0$ & $240 \pm 0.0$ \\
DZP & $34.0 \pm 2.9^{* * *}$ & $1.3 \pm 0.1^{* * *}$ \\
CLEO $30 \mathrm{mg} / \mathrm{kg}$ & $0.3 \pm 0.3$ & $218.3 \pm 21.7$ \\
CLEO $100 \mathrm{mg} / \mathrm{kg}$ & $0.1 \pm 0.1$ & $217.2 \pm 22.8$ \\
CLEO $300 \mathrm{mg} / \mathrm{kg}$ & $0.0 \pm 0.0$ & $240.0 \pm 0.0$
\end{tabular}

Note: Vehicle (10 mL/kg, p.o.), Citrus limon essential oil (CLEO, 30, 100, and $300 \mathrm{mg} / \mathrm{kg}$, p.o.), and diazepan (DZP, 1.5 $\mathrm{mg} / \mathrm{kg}$, i.p.). Data represent the means \pm SEM of eight mice. ${ }^{* *} \mathrm{p}<0.001$ compared with vehicle group using ANOVA and Dunnett's test as the post hoc test.

Table 3 shows that the treatment with vehicle and CLEO failed to cause catalepsy-like behavior in all the tested times, whilst Haloperidol ( $1 \mathrm{mg} / \mathrm{kg}$, i.p.) produces a statistically significant cataleptic effect $(\mathrm{p}<0.001)$.

Table 3. Effects of Citrus limon essential oil (CLEO) on catalepsy assay.

\begin{tabular}{lcccc}
\hline \multicolumn{1}{c}{ Treatments } & $\mathbf{3 0} \mathbf{~ m i n}$ & $\mathbf{6 0} \mathbf{~}$ in & $\mathbf{1 2 0} \mathbf{~}$ in & $\mathbf{1 8 0 ~} \mathbf{~}$ in \\
\hline Vehicle & $10.38 \pm 0.9$ & $15.5 \pm 1.4$ & $15.5 \pm 1.3$ & $24.0 \pm 1.5$ \\
HALO & $108.3 \pm 7.7^{\star * *}$ & $147.0 \pm 10.6^{* * *}$ & $215.5 \pm 16.8^{* * *}$ & $251.2 \pm 9.6^{* * *}$ \\
CLEO $30 \mathrm{mg} / \mathrm{kg}$ & $10.22 \pm 2.5$ & $22.01 \pm 4.4$ & $17.3 \pm 3.3$ & $18.36 \pm 3.7$ \\
CLEO $100 \mathrm{mg} / \mathrm{kg}$ & $11.3 \pm 1.7$ & $14.9 \pm 0.6$ & $28.2 \pm 1.0$ & $27.4 \pm 2.3$ \\
CLEO $300 \mathrm{mg} / \mathrm{kg}$ & $13.32 \pm 1.1$ & $19.1 \pm 2.7$ & $43.67 \pm 4.4$ & $42.0 \pm 4.1$
\end{tabular}

Note: Vehicle (10 mL/kg, p.o.), Citrus limon essential oil (CLEO, 30, 100, and $300 \mathrm{mg} / \mathrm{kg}$, p.o.), and haloperidol (HALO, $1 \mathrm{mg} / \mathrm{kg}$, i.p.). Data represent the means \pm SEM of eight mice according to treatment time. ${ }^{* * *} p<0.001$ compared with vehicle group using ANOVA and Dunnett's test as the post hoc test.

\section{DISCUSSION}

Anxiety is an affective essential emotion and, in some cases, is considered as a performance propeller. However, in some people this feeling becomes excessive and harmful, characterizing a psychic disorder. The pharmacotherapy of anxiety disorders may require weeks to become clinically effective or may be associated with side effects that compromise daily activities $[28,29]$.

The use of animal models is the preclinical research basis in the psychopharmacology of psychiatric disorders, and they are employed both in the study of a specific effect and in the screening to obtain new drug prototypes and their involved mechanisms [30,31].

Based on the above, the present study investigated the anxiolytic mechanism and the hypnotic-sedative effect of Citrus limon essential oil, as well as its effects on the motor coordination performance.

Fujimori [32] proposed that increased barbiturate hypnosis is a good indicator of CNS depressant activity. Thus, for the study of substances with hypnotic-sedative properties, the barbiturate-induced sleep model is the most widely used animal model. Results showed that CLEO at a $300 \mathrm{mg} / \mathrm{kg}$ dose, p.o., promoted decreased sleep latency and increased total sleep time, which confirms a hypnotic-sedative activity. One of the approaches that could be made is that CLEO may be modifying in some way the neurotransmission involved in sleep modulation.

In the sleep regulation process, three hypothalamic subdivisions are important in the sleep-wake cycle: anterior, posterior and lateral hypothalamus. During the circadian rhythm, the inhibitory GABAergic system of the anterior hypothalamus is responsible for the onset and maintenance of sleep, while the aminergic, histaminergic, orexinergic nuclei of the posterior and lateral hypothalamus are active during wakefulness [33, 34].

Substances presenting GABAergic activity, such as benzodiazepines, at higher doses than those used in the anxiety treatment, promote hypnosis by acting at the $\mathrm{GABA}_{A}$ receptor, resulting in increased GABA affinity to the receptor. In fact, one of the side effects in this drug class is hypnosis [35]. Secondary metabolites previously studied, such as limonene, myrcene, $\alpha$-pinene, and $\beta$-pinene have demonstrated hypnoticsedative effects as they enhanced sleeping time in mice [36-39]. The same metabolites were identified in 
CLEO through GC/MS as the major constituents. This study results corroborate this hypothesis since CLEO showed anxiolytic and hypnotic effects at the highest dose.

After confirming the hypnotic-sedative activity, the anxiolytic activity was evaluated. Most experimental models that evaluate the anxiety behavior is based on conflicting situations, such as placing an animal new and stressful environment or in front of a predator [40].

For a better evaluation of the anxiolytic potential it is necessary to use at least two animal models $[41,42]$. Thus, the elevated-plus maze and the light-dark box tests were used to validate the hypothesis that CLEO has an anxiolytic effect.

The elevated-plus maze test is considered an etiologically valid model since it uses a natural stimulus fear of a new open space and fear of balance on a suspended and relatively narrow platform - that can induce anxiety in humans. This model is based on the fact that rodents avoid exposing themselves to open areas, which are thought to be more aversive, showing a preference for enclosed areas protected by walls. This reaction is suppressed by anxiolytic drugs and potentiated by anxiogenic agents. Thus, the number of entries and time into open arms are the highest indicators of anxiety reduction in the elevated-plus maze test [22].

The 100 and $300 \mathrm{mg} / \mathrm{kg}$ doses of CLEO increased the number of entries and the percentage of time into open arms, suggesting a statistically significant anxiolytic effect compared to the one showed by diazepam.

These results corroborate previous studies of authors that evaluated the anxiolytic effect in some species of genus Citrus. Faturi and coauthors [6] and Leite and coauthors [43] performed studies with $C$. sinensis and $C$. aurantium essential oils, respectively, in which they aimed to evaluate anxiolytic activity through the elevated-plus maze test from an inhalation route of administration. $C$. sinensis, in the two largest doses tested, revealed statistically significant differences regarding the number of entries and the percentage of time into open arms when compared to vehicle. However, in the three concentrations of $C$. arantium tested, no significant statistical differences were observed in any of the analyzed parameters - which were the same parameters used in the present study.

Vieira and coauthors [44] evaluated three different doses of a methanolic extract from C. limon leaves, p.o., in which they concluded that in the elevated-plus maze test only the largest dose did not change any of the analyzed parameters - also the same parameters used in the present study.

In order complement the likely anxiolytic effects of CLEO, the light-dark box test was performed. This model is based on the rodents' fear of illuminated areas and their spontaneous and exploratory behavior to a new and illuminated environment [45]. After anxiolytic drugs treatment, the apparent fear of remaining or moving to the lighted area is removed [46].

The results in this study indicate that CLEO reduced fear against the lighted environment, as it increased the number of transitions between the light and dark compartment. In addition, an increase in the percentage of time into the light area was shown, similar to what is observed in animals treated with diazepam. These results corroborate the anxiolytic effect found in the elevated-plus maze test.

Citrus latifolia essential oil [47] produced an increase in the time into light compartment, while $C$. aurantium was able to increase both time into light compartment and the number of transitions between lightdark compartments [45]. According to Faturi and coauthors [6], C. sinensis essential oil also increases the time into light compartment; although in their study the number of transitions between the light-dark compartments was not evaluated.

The present data point to an anxiolytic effect from CLEO, which is associated with the terpenes described in the GC/MS analysis. Terpenes and terpenoids are the primary constituents of essential oils from many types of medicinal plants. Terpenes have low molecular weight and usually low water solubility, and due to this they can penetrate the blood-brain barrier and produce their anxiolytic, sedative, and anticonvulsant effects on the CNS $[48,49]$. Such effects may be related to the action of a metabolite (isolated) or more (combined).

Similarly to our results, Satou and coauthors [8] submitted $C$. junos essential oil to GC and observed similar chemicals in its composition, such as limonene, p-cymene, $y$-terpinene, myrcene, and a-pinene. In their in vivo evaluation, it was found that the essential oil presented an anxiolytic-like effect as well as an increase in locomotor activity.

It is well reported in literature the anxiolytic activity of two isolated secondary metabolites: limonene $[50,51]$ and $\alpha$-pinene $[16,52]$. All these articles highlight action of compounds on the CNS evidencing the anxiolytic property from CLEO. 
Hence, based on the results, CLEO treatment showed an anxiolytic effect without motor coordination impairment that is a characteristic effect in sedative drugs. Thereon, in order to elucidate previous results, the mechanisms where CLEO could modulate its activity were investigated.

As mentioned before, GABAergic system is undoubtedly involved in the anxiety neurochemistry. Studies using GABAergic receptor antagonists, such as flumazenil, a drug that block the benzodiazepines binding site at the GABA receptor, show the anxiolytic effect of diazepam may be reversed [53].

There are several anxiety studies involving $\mathrm{GABA}_{\mathrm{A}}$ and $5-\mathrm{HT}_{1 \mathrm{~A}}$ receptor ligands as likely sites of action of anxiolytic drugs. Neurochemical studies indicate that buspirone acts preferentially on $5-\mathrm{HT}_{1 \mathrm{~A}}$ autoreceptors in raphe nuclei [54]. Activation of these presynaptic autoreceptor decreases the amount of serotonin postsynaptically. Thus, the anxiogenic effect of serotonin seems to be suppressed by the buspirone treatment.

Furthermore, preclinical and clinical studies indicate an important role of $5-\mathrm{HT}_{2 \mathrm{~A}}$ and $5-\mathrm{HT}_{2 \mathrm{C}}$ receptors in the anxiety pathophysiology. Literature evidence indicates that the use of $5-\mathrm{HT}_{2 \mathrm{~A} / \mathrm{C}}$ receptor antagonists exhibit anxiolytic properties. They decrease the serotonin binding to these receptors after a prolonged treatment, which suggests a down regulation of the 5- $\mathrm{HT}_{2 \mathrm{~A} / \mathrm{C}}$ receptors [55].

Considering the supposedly effects mediated by the 5-HT receptors blockade, they have been aimed as new treatment strategies of anxiety disorders - not only because of their beneficial effects, but also because they do not induce undesirable side effects usual in anxiolytic treatment.

This study results showed that ketanserin pre-treatment $(0.5 \mathrm{mg} / \mathrm{kg}$, i.p.) did not reverse the CLEO anxiolytic effect (300 mg/ kg, p.o.) that was observed in the elevated-plus maze and light-dark box tests. The same was observed with NAN-190 pre-treatment $(0.5 \mathrm{mg} / \mathrm{kg}$, i.p.), which also did not reverse the analyzed parameters after CLEO administration. This founds suggest the lack of involvement of $5-\mathrm{HT}_{1 \mathrm{~A}}$ pre-synaptic and 5-HT $2 \mathrm{~A} / \mathrm{C}$ postsynaptic serotonin receptors in the anxiolytic mechanism presented by CLEO.

On the other hand, flumazenil pre-treatment reversed not only the diazepam but also CLEO anxiolytic effect, suggesting that the essential oil may reduce anxiety by a similar mechanism of action of benzodiazepines on $\mathrm{GABA}_{A}$ receptors. Another mechanism that may be occurring is an increase in GABAergic neurotransmission either by stimulating the GABA synthesis/release, or by inhibiting its degradation.

Among species of Rutaceae family, some of them, such as $C$. aurantium subsp. bergamia and Spiranthera odoratissima, had the anxiolytic mechanism of their essential oil investigated. These studies suggest that $C$. aurantium subsp. bergamia essential oil is involved with a noradrenergic component in the hypothalamic-pituitary-adrenal axis that reduce corticosterone levels [7]. While the S. odoratissima anxiolytic effect seems to be related to the serotonergic system, which may be mediated by $5-\mathrm{HT}_{1 \mathrm{~A}}$ receptors since NAN-190 reversed the buspirone and the studied essential oil effects [56].

CLEO results suggest an anxiolytic activity possibly modulated at the benzodiazepines binding site in the $\mathrm{GABA}_{A}$ receptor. However, these receptor agonists exhibit several side effects, including muscle relaxation that causes a motor coordination impairment in patients.

Therefore, rotarod test was performed in order to evaluate the CLEO effect on the motor coordination system.

In this experimental model, the greater the muscle impairment, the lower the latency to the first fall, which is explained by fact that the animal will not be able to stay on the rotating bar. Also, the number of falls will be higher if the animal presents a motor incoordination [19]. Animals treated with CLEO did not show significant differences in the latency and number of falls when compared to the group treated with vehicle, which shows that the essential oil does not interfere in the animals' motor response. Thus, a myorelaxant or a neurotoxic effect may be ruled out.

Lack of effect on motor coordination was also observed in rodents treated other species of the Rutaceae family. For example, C. latifolia, C. reticulata, and C. aurantium, essential oils; Casimiroa eduli leaves ethanolic extract $[45,47,57]$.

After observing that CLEO did not change the mice motor activity, the catalepsy test was performed in order to confirm this lack of effect. Decreases in brain dopamine lead to catalepsy, quantified by the time a rat remains with its forepaws resting on a suspended horizontal bar.

Drug-induced catalepsy in rodents is a valid experimental model for assessing extrapyramidal effects caused by blockade of dopaminergic $D_{2}$ receptors present in postsynaptic neurons in the nigrostriatal region. The use of the haloperidol antagonist, preferred for the $D_{2}$ receptor, has been reported to increase the cataleptic effect in a time-dependent manner [58]. Therefore, this behavior was tested at four different times after the treatments. They are considered a useful indicator in the search for potentially active substances that may result in side effects that compromise the skeletal muscle. 
CLEO oral treatment did not induce a cataleptic behavior in animals, differently from those treated with Haloperidol (1 mg/ kg, i.p.), in which they had a progressively increased motor impairment (30 to 180 minutes post-treatment).

Alfieriand coauthors [59] studies showed different results, where $C$. paradisi oral treatment prolonged the catalepsy time in mice. Manivasagam and coauthors [60] evaluated the effect of hesperidin, a flavone found in Citrus species, such as $C$. unshiu, $C$. aurantium, and $C$. sinensis, and the results showed that this metabolite also induced a cataleptic effect.

\section{CONCLUSION}

Based on results, it is possible to assure that CLEO induces anxiolytic and hypnotic-sedative effects. However, even though this effect involves an interaction between the essential oil and the GABAergic system, it does not cause a motor coordination deficit.

So far, it cannot be said which CLEO constituents or metabolites are responsible for the presented effect, nor whether this activity is due to a direct receptor activation or an indirect effect on the increase of GABA levels.

Funding: This research was funded by the INCT-INOFAR under grant number 573.564/2008-6; CNPQ under grant number 479822/2013-1; CNPQ under grant number 485854/2011-2, CNPQ under grant number 404344/2012-7, FAPEAL under grant number Pronem 20110722-006-0018-0010), CAPES, CNPq, MCT, and FINEP.

Conflicts of Interest: The authors declare no conflict of interest.

\section{REFERENCES}

1. World Health Organization [Internet]. Depression and Other Common Mental Disorders: Global Health Estimates, 2017. Available from: http:// https://apps.who.int/iris/bitstream/handle/10665/254610/WHO-MSD-MER-2017.2eng.pdf/

2. Ferreri MC, Gutiérrez ML, Gravielle MC. Tolerance to the sedative and anxiolytic effects of diazepam is associated with different alterations of GABAAreceptors in rat cerebral cortex. Neuroscience. 2015;310:152-62.

3. Bradley BF, Bridges NJ, Starkey NJ, Brown SL, Lea RW. Anxiolytic and anxiogenic drug effects on male and female gerbils in the black-white box. Behav. Brain Research. 2011;216(1):285-92.

4. Fradelos E, Komini A, The use of essential oils as a complementary treatment for anxiety. Am J Nurs Sci. 2015;4(2):1-5.

5. Zhang N, Yao L. Anxiolytic effect of essential oils and their constituents: a review. J Agric Food Chem. 2019;67(50):13790-808.

6. Faturi CB, Leite JR, Alves PB, Canton AC, Teixeira-Silva F. Anxiolytic-like effect of sweet orange aroma in Wistar rats. Prog Neuro-Psychopharmacol Biol Psychiatry. 2010;34(4):605-9.

7. Saiyudthong $S$, Marsden CA. Acute effects of bergamot oil on anxiety-related behaviour and corticosterone level in rats. Phytother Res. 2011;25(6):858-62.

8. Satou T, Miyahara N, Murakami S, Hayashi S, Koike K. Differences in the effects of essential oil from Citrus junos and (+)-limonene on emotional behavior in mice. J Essent Oil Res. 2012;24(5):493-500.

9. Chaves Neto G, Braga JEF, Alves MF, De Morais Pordeus LC, Dos Santos SG, Scotti MT, et al. Anxiolytic effect of Citrus aurantium L. in crack users. Evid-Based Complementary Altern Med. 2017:1-8.

10. Farshbaf-Khalili A, Kamalifard M, Namadian M. Comparison of the effect of lavender and bitter orange on anxiety in postmenopausal women: a triple-blind, randomized, controlled clinical trial. Complement Ther Clin Pract. 2018;31:132-8.

11. Watanabe E, Kuchta K, Kimura M, Rauwald HW, Kamei T, Imanishi J. Effects of bergamot (Citrus bergamia (Risso) Wright \& Arn.) essential oil aromatherapy on mood states, parasympathetic nervous system activity, and salivary cortisol levels in 41 healthy females. Complement Med Res. 2015;22(1):43-9.

12. Caputo L, Reguilon MD, Mińarro J, De Feo V, Rodriguez-Arias M. Lavandula angustifolia essential oil and linalool counteract social aversion induced by social defeat. Molecules. 2018:23(10):2694.

13. Harada $\mathrm{H}$, Kashiwadani $\mathrm{H}$, Kanmura $\mathrm{Y}$, Kuwaki T. Linalool odor-induced anxiolytic effects in mice. Front Behav Neurosci. 2018;12:241.

14. Lima NGPB, De Sousa DP, Pimenta FCF, Alves MF, De Souza FS, Macedo RO, et al. Anxiolytic-like activity and GC-MS analysis of (R)-(+)-limonene fragrance, a natural compound found in foods and plants. Pharmacol Biochem Behav. 2013;103(3):450-4. 
15. Satou T, Miyagawa M, Seimiya $H$, Yamada $H$, Hasegawa $T$, Koike K. Prolonged anxiolytic-like activity of sandalwood (Santalum album L.) oil in stress-loaded mice. Flavour Fragr J. 2014;29(1):35-8.

16. Yang H, Woo J, Pae AN, Um MY, Cho N-C, Park KD, et al. a-Pinene, a major constituent of pine tree oils, enhances non-rapid eye movement sleep in mice through $\mathrm{GABA}_{A}$-benzodiazepine receptors. Mol Pharmacol. 2016;90(5):530-9.

17. Khan RA, Riaz A. Behavioral effects of Citrus limon in rats. Metab Brain Dis. 2015;30(2):589-96.

18. Adams RP. Identification of essential oil components by gas chromatography/mass spectrometry. 4th ed. Carol Stream: Allured Publ. Corp.; 2007

19. Carlini EA, Burgos V. Screening farmacológico de ansiolíticos: metodologia laboratorial e comparação entre diazepam e clorobenzepam. Rev Assoc Bras Psiquiatria. 1979;1(1):25-31.

20. Novas ML, Wolfman C, Medina JH, De Robertis E. Proconvulsant and anxiogenic effects of $n$-butyl beta carboline3-carboxylate, an endogenous benzodiazepine binding inhibitor from brain. Pharmacol Biochem Behav. 1988;30(2):331-6.

21. Lister R. The use of a plus-maze to measure anxiety in the mouse. Psychopharmacology. 1987;92(2):180-5.

22. Pellow S, File SE. Anxiolytic and anxiogenic drug effects on exploratory activity in an elevated plus-maze: a novel test of anxiety in the rat. Pharmacol Biochem Behav. 1986;24(3):525-9.

23. Crawley J, Goodwin FK. Preliminary report of a simple animal behavior model for the anxiolytic effects of benzodiazepines. Pharmacol Biochem Behav. 1980;13(2)167-70.

24. Savić MM, Obradović DI, Ugresić ND, Cook JM, Yin W, Bokonjić DR, Bidirectional effects of benzodiazepine binding site ligands in the elevated plus-maze: differential antagonism by flumazenil and beta-CCt. Pharmacol Biochem Behav. 2004;79(2):279-90.

25. Huo FQ, Huang FS, Lv BC, Chen T, Feng J, Qu CL, et al. Activation of serotonin $1 \mathrm{~A}$ receptors in ventrolateral orbital cortex depresses persistent nociception: a presynaptic inhibition mechanism. Neurochem Int. 2010;57(7):749-55.

26. Dunham NW, Miya TS. A note on a simple apparatus for detecting neurological deficit in rats and mice ${ }^{\star *}$ College of Pharmacy, University of Nebraska, Lincoln 8. J Am Pharm Assoc (Scientific ed.). 1957;46(3):208-209.

27. Sanberg PR, Bunsey MD, Giordano M, Norman AB. The catalepsy test: its ups and downs. Behav Neurosci. 1988:102(2):748-59.

28. Baldessarini RJ. Fármacos e o tratamento dos distúrbios psiquiátricos: depressão e distúrbios de ansiedade. In: Hardman JG, Limbird LE, editors. Goodman \& Gilman's: the pharmacological basis of therapeutics. New York: McGraw Hill; 2005. p. 290-334

29. Charney DS, Mihic SJ, Harris RA. Hipnóticos e sedativos. In: Hardman JG, Limbird LE, editors. Goodman \& Gilman's: the pharmacological basis of therapeutics. New York: McGraw Hill; 2005. p. 338.

30. File SE, Behavioural detections of anxiolytic action. In: Elliot JM, Heal DJ, Marsden CA, editors. Experimental approaches to anxiety and depression. Chichester: Wiley-Blackwell, Chichester; 1992. p. 24-44.

31. Green S, Hodges H. Animal models of anxiety. In: Willner P, editor. Behavioural models in psychopharmacology. New York: Cambridge University Press, New York; 1991. p. 21-9.

32. Fujimori $\mathrm{H}$. Potentiation of barbital hypnosis as an evaluation method for central nervous system depressants. Psychopharmacologia. 1965;7(5):374-8.

33. Nitz D, Siegel JM. GABA release in the locus coeruleus as a function of sleep/wake state. Neuroscience. 1997;78(3):795-801.

34. Saper CB, Chou TC, Scammell TE. The sleep switch: hypothalamic control of sleep and wakefulness. Trends Neurosci. 2001;24(12):726-31.

35. Bateson AN. Further potential of the GABA receptor in the treatment of insomnia. Sleep Med. 2006;7 Suppl 1:S3S9.

36. Do Vale TG, Furtado EC, Santos JG, Viana GSB. Central effects of citral, myrcene and limonene, constituents of essential oil chemotypes from Lippia alba (mill.) N.E. Brown. Phytomedicine. 2002;9(8):709-14.

37. Freitas JCBR, Presgrave OAF, Fingola FF, Menezes MAC, Paumgartten FJR, Effect of $\beta$-myrcene on pentobarbital sleeping time. Braz J Med Biol Res. 1993;26(5): 519-23.

38. Guzmán-Gutiérrez SL, Gómez-Cansino R, García-Zebadúa JC, Jiménez-Pérez NC, Reyes-Chilpa R. Antidepressant activity of Litsea glaucescens essential oil: identification of $\beta$-pinene and linalool as active principles. J Ethnopharmaco. 2012;143(2):673-9.

39. Salehi B, Upadhyay S, Orhan IE, Jugran AK, Jayaweera SLD, Dias DA, et al. Therapeutic potential of $\alpha$ - and $\beta$ pinene: a miracle gift of nature. Biomolecules. 2019;9(11):738,1-37.

40. Blanchard RJ, Yudko EB, Rodgers RJ, Blanchard DC. Defense system psychopharmacology: an ethological approach to the pharmacology of fear and anxiety. Behav Brain Res. 1993;58(1-2):155-65. 
41. Do Rego JC, Viana AF, Le Maître E, Deniel A, Rates SMK, Leroux-Nicollet I, et al. Comparisons between anxiety tests for selection of anxious and non anxious mice. Behav Brain Res. 2006;169(2):282-8.

42. Dourish CT, Grewal SS, Shepherd JK, Stanhope KJ, Bill DJ, Fletcher A. Benefits of ethological analysis of behaviour. Trends Pharmacol Sci. 1995;16(8)260-1.

43. Leite MP, Fassin J, Baziloni EMF, Almeida RN, Mattei R, Leite JR. Behavioral effects of essential oil of Citrus aurantium L. inhalation in rats. Braz J Pharmacogn. 2008;18 Suppl:661-6.

44. Vieira FCR, Cardoso KMF, Melo CHS, Freitas RM, Feitosa CM, editor. Estudo da atividade ansiolítica do extrato etanólico das folhas de Citrus limon. 34 Reunião Anual da Sociedade Brasileira de Química; 2011 May 23-26; Florianópolis, Brazil. Available from: http://sec.sbq.org.br/cdrom/34ra/resumos/T0434-2.pdf

45. Pultrini AM, Galindo LA, Costa M. Effects of the essential oil from Citrus aurantium L. in experimental anxiety models in mice. Life Sci. 2006;78(15)1720-5.

46. Costall B, Jones BJ, Kelly ME, Naylor RJ, Tomkins DM. Exploration of mice in a black and white test box: validation as a model of anxiety. Pharmacol Biochem Behav. 1989;32(3)777-85.

47. Gargano AC. Estudo da atividade ansiolítica e sedativa do óleo essencial das cascas de frutos de espécies do gênero Citrus [dissertation]. Botucatu: Universidade Estadual Paulista; 2007.

48. De Sousa DP. Analgesic-like activity of essential oils constituents. Molecules. 2011;16(13):2233-52.

49. Quintans-Júnior LJ, Souza TT, Leite BS, Lessa NMN, Bonjardim LR, Santos MRV, et al. Phythochemical screening and anticonvulsant activity of Cymbopogon winterianus Jowitt (Poaceae) leaf essential oil in rodents. Phytomedicine. 2008;15(8):619-24.

50. De Almeida AAC, Costa JP, De Carvalho RBF, De Sousa DP, De Freitas RM. Evaluation of acute toxicity of a natural compound (+)-limonene epoxide and its anxiolytic-like action. Brain Res. 2012;1448:56-62.

51. De Almeida AAC, De Carvalho RBF, Silva OA, De Sousa DP, De Freitas RM. Potential antioxidant and anxiolytic effects of (+)-limonene epoxide in mice after marble-burying test. Pharmacol Biochem Behav. 2014;118:69-78.

52. Kasuya H, lida S, Ono K, Satou T, Koike K. Intracerebral distribution of a-pinene and the anxiolytic-like effect in mice following inhaled administration of essential oil from Chamaecyparis obtusa. Nat Prod Commun. 2015;10(8):1479-82.

53. Kim J, Gorman J. The psychobiology of anxiety. Clin Neurosci Res. 2005;4(5-6):335-47.

54. Hoyer D, Martin G. 5-HT receptor classification and nomenclature: towards a harmonization with the human genome. Neuropharmacology. 1997;36(4-5):419-28.

55. Deakin JFW. 5-HT2 receptors, depression and anxiety. Pharmacol Biochem Behav. 1988;29(4):819-20.

56. Galdino PM, Nascimento MVM, De Sousa FB, Ferreira RN, De Paula JR, Costa EA. Central activities of hydroalcoholic extract from Lafoensia pacari A. St.-Hil. stem bark. Braz J Pharm Sci. 2010;46(3):455-62.

57. Carvalho-Freitas MIR, Costa M. Anxiolytic and sedative effects of extracts and essential oil from Citrus aurantium L. Biol Pharm Bull. 2002;25(12):1629-33.

58. Banasikowski TJ, Beninger RJ. Haloperidol conditioned catalepsy in rats: a possible role for $D_{1}$-like receptors. Int J Neuropsychopharmacol. 2012;15(10):1525-34.

59. Alfieri G, Mendoza L, Torres F, Vargas S, Centurión de Wenninger C, Variación del tiempo de catalepsia inducida por haloperidol en ratones debido a la administración de C. paradisi. Med. Actual. 2008;9(1):4-7.

60. Manivasagam T, Nataraj J, Tamilselvam K, Essa MM, Janakiraman U, Antioxidant and anti-inflammatory potential of hesperidin against 1-methyl-4-phenyl-1, 2, 3, 6-tetrahydropyridine-induced experimental Parkinson's disease in mice. Int J Nutr Pharmacol Neurol Dis. 2013;3(3)294-302. 